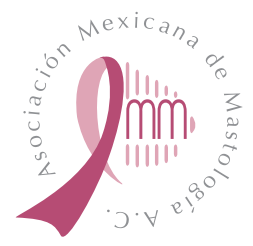

Revista

Mexicana de

Mastología

Vol. 11, No. 1, Ene-Abr 2021

doi: $10.35366 / 99275$

\title{
Coronavirus de tipo 2 causante del síndrome respiratorio agudo severo, un virus que llegó para quedarse
}

\author{
Severe acute respiratory syndrome coronavirus 2, a virus that is here to stay \\ Eliud Salvador Aguilar Barrera, ${ }^{*, \neq}$ Raquel Gómez Pliego, ${ }^{\S}$ Judith Espinosa Raya," \\ José Correa Basurto, II Jazmín García Machorro ${ }^{\ddagger}$
}

\begin{abstract}
* Centro Interdisciplinario de Ciencias de la Salud Unidad Milpa Alta, Instituto Politécnico Nacional. Ciudad de México, Maestro en Ciencias y estudiante de doctorado.

${ }^{\ddagger}$ Laboratorio de Medicina de Conservación, Escuela Superior de Medicina, Instituto Politécnico Nacional, Ciudad de México, Doctora en Ciencias. $\S$ Departamento de Ciencias Biológicas, Sección de Ciencias de la Salud Humana, Facultad de Estudios Superiores Cuautitlán (UNAM), Doctora en Ciencias.

"Laboratorio de

Neurofarmacología, Escuela Superior de Medicina, Instituto Politécnico Nacional, Doctora en Ciencias.

I Laboratorio de Diseño y Desarrollo de Nuevos Fármacos e Innovación Biotecnológica, Escuela Superior de Medicina, Instituto Politécnico Nacional, Doctor en Ciencias.

Correspondencia: Jazmín García Machorro E-mail: jgarcia@ipn.mx
\end{abstract}

\section{Resumen}

Los coronavirus son virus que afectan principalmente a los animales y, en diferentes circunstancias, pueden afectar a humanos como sucedió con los virus del síndrome respiratorio agudo severo (SARS) y el síndrome respiratorio de oriente medio (MERS). Dichos virus causaron alerta epidemiológica, sin desencadenar una pandemia; debido a que presentan características que los hacen menos eficientes en la infección de humano a humano. Sin embargo, el virus del síndrome respiratorio agudo severo 2 (SARS-CoV-2) además de superar la barrera de especie, ha demostrado ser eficiente en la transmisión de humano a humano, su tiempo de incubación es de cuatro a 14 días y existen casos de personas asintomáticas, lo que permite mayor propagación. Por las características anteriores nos enfrentamos a un virus respiratorio que está provocando una pandemia con un número de muertes mayor a la causada por influenza en 1957 y 1968. La mitigación de la actual pandemia es un reto para la salud pública y las medidas de protección siguen siendo las mismas que las divulgadas en la pandemia de 1918 (antes de los antibióticos y antivirales). El presente trabajo describe los antecedentes del origen y características del SARS-CoV-2, un virus que llegó para quedarse.

Palabras clave: Coronavirus, origen, evolución, mutación, SARS-CoV-2, COVID-19.

\section{ABSTRACT}

Coronaviruses are viruses that mainly affect animals; in different circumstances they can affect humans, as did the Severe Acute Respiratory Syndrome (SARS) and the Middle East Respiratory Syndrome (MERS) viruses. These viruses caused an epidemiological alert, without triggering a pandemic; because they have characteristics that make them less efficient in human-to-human infection. However, the Severe Acute Respiratory Syndrome virus 2 (SARS-CoV-2), in addition to overcoming the species barrier, has proven to be efficient in human-tohuman transmission, its incubation time is four to 14 days, and some people are asymptomatic, allowing further spread. Due to the previous characteristics, the SARS-CoV-2 is causing a pandemic with a number of deaths greater than that caused by influenza in 1957 and 1968. Mitigating the current pandemic is a challenge for public health and the protection measures remain the same as those disclosed in the 1918 pandemic (before antibiotics and antivirals). This work describes the background of the origin and characteristics of SARS-CoV-2, a virus that is here to stay.

Keywords: Coronavirus, origin, evolution, mutation, SARS-CoV-2, COVID-19.

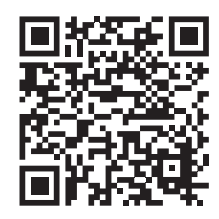

Citar como: Aguilar BES, Gómez PR, Espinosa RJ, Correa BJ, García MJ. Coronavirus de tipo 2 causante del síndrome respiratorio agudo severo, un virus que llegó para quedarse. Rev Mex Mastol. 2021; 11 (1): 9-17. https://dx.doi. org/10.35366/99275 


\section{INTRODUCCIÓN}

Los coronavirus (CoVs) circulan principalmente entre animales, pero han evolucionado y pueden infectar a los humanos, por lo que su transmisión se considera zoonótica. En humanos pueden causar desde un resfriado común hasta una enfermedad grave y la muerte. Los CoVs son virus envueltos y se han clasificado en el grupo IV de Baltimore, de acuerdo a las características del genoma de RNA de cadena sencilla de polaridad positiva, de 26 a 32 kilobases de longitud. Se han agrupado en una familia denominada Coronaviridae, y subfamilia coronaviridae, orden nidovirus. ${ }^{1}$ La subfamilia, a su vez, se divide en cuatro géneros: Alphacoronavirus $(\alpha \mathrm{CoVs})$, Betacoronavirus ( $\beta \mathrm{CoVs}), \mathrm{Gam}$ macoronavirus ( $\gamma \mathrm{CoVs}$ ) y Deltacoronavirus $(\delta \mathrm{CoVs})$. Los $\alpha \mathrm{CoVs}$ y $\beta \mathrm{CoVs}$ afectan principalmente a murciélagos y roedores; los $\gamma \mathrm{CoVs}$ y $\delta \mathrm{CoV}$ s afectan a aves. Hasta diciembre 2020 se han descrito siete CoVs con capacidad de infectar a humanos, también conocidos como coronavirus humanos (HCoV): HCoV-229E, HCoV-NL63, HCoV-OC43, HCoV-HKU1, SARS-CoV, MERS-CoV y SARS-CoV-2; en la Tabla 1 se puede apreciar la clasificación en género y linaje.

\section{GÉNERO $\alpha$ CoVs CON CAPACIDAD DE INFECTAR A HUMANOS}

\section{HCoV-229E o 229E}

La cepa 229E fue aislada en 1966, en conjunto con otros virus de muestras del tracto respiratorio humano de pacientes con resfriado común. Se aislaron en células de riñón y células WI38 (fibroblastos de pulmón humano), y se concluyó que no estaban relacionados antigénicamente con los myxovirus. ${ }^{2}$ Fue hasta el año 2012 cuando se reportó la primer secuencia del genoma completo del virus 229E. ${ }^{3}$ Los datos clínicos de la infección incluyen malestar general, cefalea, secreción nasal, estornudos y dolor de garganta. ${ }^{4}$ Una pequeña porción de pacientes (10-20\%) presentará fiebre y tos. Por lo anterior, es clínicamente indistinguible de las infecciones de vías respiratorias causadas por otros patógenos, como el rinovirus y la influenza $A ;{ }^{5}$ al igual que estos virus, su localización y distribución es a nivel mundial. ${ }^{6}$

\section{HCoV-NL63 o NL63}

Este virus se aisló a finales del 2004 en los Países Bajos, de un niño de siete meses con bronquiolitis, coriza, conjuntivitis y fiebre. ${ }^{7}$ De manera

\begin{tabular}{|c|c|c|c|}
\hline Género & Hospedero natural & & Cepas con afectación a humanos \\
\hline \multirow[t]{2}{*}{$\alpha$ CoVs } & Murciélagos y roedores & & $\begin{array}{l}\text { HCoV-299E (1966) } \\
\text { HCoV-NL63 (2004) }\end{array}$ \\
\hline & & $\begin{array}{c}\text { Linaje } \\
\mathrm{A}\end{array}$ & $\begin{array}{l}\text { HCoV-OC43 (1967) } \\
\text { HCoV-HKU1 (2005) }\end{array}$ \\
\hline \multirow[t]{2}{*}{$\beta$ CoVs } & Murciélagos y roedores & B & $\begin{array}{c}\text { SARS-CoV (2002) } \\
\text { SARS-CoV-2 (2019) }\end{array}$ \\
\hline & & $\begin{array}{l}\text { C } \\
\text { D }\end{array}$ & $\begin{array}{c}\text { MERS-CoV (2012) } \\
\text { No se ha detectado en humanos }\end{array}$ \\
\hline$\gamma$ CoVs & Aves & & No se ha detectado en humanos \\
\hline$\delta$ CoVs & Aves & & No se ha detectado en humanos \\
\hline
\end{tabular}

Se muestran los cuatro géneros descritos, el principal hospedero animal o también conocido como hospedero natural y las cepas que han afectado a humanos, en paréntesis el año de aparición.

$\mathrm{CoVs}=$ coronavirus, $\mathrm{HCoV}=$ coronavirus humanos, SARS-CoV = severe acute respiratory syndrome coronavirus, SARS-CoV- $2=$ severe acute respiratory syndrome coronavirus 2, MERS-CoV = Middle East respiratory syndrome coronavirus. 
independiente, en el mismo país, se describió el aislamiento del mismo virus de una muestra nasal de un niño de ocho meses con diagnóstico de neumonía. ${ }^{8}$ En el año 2005, NL63 también fue detectado en New Haven (Estados Unidos), en aproximadamente de 79 a 895 niños. ${ }^{9}$ A la fecha se considera un virus de distribución mundial, y se estima que representa el $4.7 \%$ de las infecciones respiratorias, principalmente en niños pequeños, ancianos y pacientes inmunodeprimidos. ${ }^{7}$ Las infecciones por NL63 suelen provocar una enfermedad respiratoria leve similar al resfriado común, caracterizado por tos, rinorrea, taquipnea, fiebre e hipoxia que finalmente se autolimitan. ${ }^{10}$ Adicionalmente, se ha reportado laringitis obstructiva, también conocida como crup. ${ }^{11}$

\section{GÉNERO $\beta$ CoVs CON CAPACIDAD DE INFECTAR A HUMANOS}

\section{HCoV-OC43 también nombrado OC43 (linaje A)}

Con el antecedente del aislamiento de la cepa $229 \mathrm{E}$ en 1966, los investigadores continuaron con el estudio de los agentes patógenos que causan infección de vías respiratorias; para esa fecha estimaron que del 20 al 35\% de los patógenos eran virus. En 1967 aislaron la cepa OC43 de lavados nasofaríngeos, el cultivo lo realizaron en tejido de órganos traqueales embrionados ya que no pudieron aislarla con técnicas de cultivo estándar. Estos virus exhibieron una morfología inusual muy parecida al del virus de la bronquitis infecciosa aviar (IBV). Aunque los pacientes infectados con OC43 desarrollan los mismos síntomas clínicos que los de $229 \mathrm{E}$, no se presenta reactividad cruzada serológica. ${ }^{12}$ El virus OC43 también se distribuye a nivel mundial. ${ }^{6}$

\section{SARS-CoV (linaje B)}

El nombre de este virus se debe a sus siglas en inglés «severe acute respiratory syndrome» (síndrome agudo respiratorio severo) y emergió en Cantón, China, en el año 2002. Provocó un brote de neumonía atípica y rápidamente se expandió a China, Hong Kong, Taiwán, Singapur, Vietnam y Canadá.
A la enfermedad que provoca se le conoce como SARS. Fue hasta el 12 de marzo de 2003 cuando la Organización Mundial de la Salud (OMS) emitió una Alerta Global de la epidemia de SARS. Este virus causó aproximadamente 8,000 infecciones y 800 muertes. Los datos epidemiológicos indicaron la transmisión a partir de civetas de palmeras enmascaradas (Paguma larvata) en los mercados de animales vivos. Sin embargo, las civetas silvestres o fuera de los mercados de animales resultaron negativos al aislamiento del virus. ${ }^{13}$ Por lo anterior, se presume que las civetas eran un huésped intermedio, no un reservorio para el SARS-CoV. ${ }^{14}$ Posteriormente, se encontró en los murciélagos herradura salvaje (familia Rhinolophidae), niveles detectables de anticuerpos contra el SARS-CoV y un virus similar al SARS-CoV (SARSr-Rh-Bat CoV). ${ }^{15,16}$ Llama la atención que esta clase de murciélagos se vende en los mercados de animales de China y es alimento en algunos restaurantes. La evidencia actual sugiere que el murciélago pudo ser el origen para el SARS-CoV. ${ }^{6}$ Se ha descrito que después de originarse en el murciélago, pasó a un hospedero mamífero intermediario conocido como civeta (Paguma larvata), de este modo saltó la barrera de especie e infectó a los humanos. ${ }^{17}$

\section{HCoV-HKU1 o HKU1 (linaje A)}

Este virus se identificó por primera vez en enero de 2005 a partir de aspirados nasofaríngeos de un paciente de 71 años de Hong Kong que había viajado a Shenzhen, China. El paciente se hospitalizó con diagnóstico de neumonía y bronquiolitis. El aislamiento del virus no se logró, a pesar de emplear múltiples líneas celulares (neuronas, glía mixta e inoculación intracerebral de ratones lactantes). ${ }^{18}$ Los síntomas de la infección del tracto respiratorio por HKU1 no pueden diferenciarse de las causadas por otros virus respiratorios. La mayoría de los pacientes presenta fiebre, secreción nasal y tos por infecciones en las vías respiratorias superiores; mientras que la tos productiva y disnea son síntomas comunes en la infección del tracto respiratorio inferior. ${ }^{19}$ La mayoría de las infecciones por HKU1 son autolimitadas; sin embargo, se han notificado dos muertes en pa- 
cientes con neumonía. ${ }^{20}$ En niños la infección por HKU1 es clínicamente leve, pero se asocia con una alta incidencia de convulsiones y en un paciente se diagnosticó meningitis. ${ }^{21,22} \mathrm{Se}$ han detectado casos fuera del continente asiático, en países como Estados Unidos, Australia, Francia y Brasil, por lo que se considera que su distribución es a nivel mundial. ${ }^{6}$

\section{MERS-CoV (linaje C)}

Recibe su nombre por sus siglas en inglés «Middle east respiratory syndrome coronavirus». En septiembre de 2012 se aisló por primera vez el virus a partir de muestra de esputo de un paciente saudí de 60 años con diagnóstico de neumonía aguda que desarrolló insuficiencia renal con desenlace fatal. Las manifestaciones clínicas son muy variables y van desde fiebre, tos, escalofríos, dolor de garganta, mialgia y artralgia, disnea con progresión a neumonía, síntomas gastrointestinales y lo más llamativo es la insuficiencia renal que no se había reportado para otros coronavirus. ${ }^{23} \mathrm{Se}$ describió que el virus fácilmente se replica en cultivo celular y en la identificación molecular se encontró que se trata de un coronavirus diferente al SARS-CoV aislado en 2003. ${ }^{24}$ En estudios en dromedarios y camellos de Oriente Medio en África se describió la presencia de anticuerpos neutralizantes contra el MERS$\mathrm{CoV} ;{ }^{25,26}$ adicionalmente, el virus se pudo aislar de hisopados nasales de camellos; lo que indica una fuente potencial de infección. Sin embargo, muchos casos confirmados carecen de antecedentes de contacto con camellos, ${ }^{27}$ lo que sugiere transmisión directa de persona a persona, o a través del contacto con algún otro animal aún no identificado. ${ }^{6}$ Desde su aislamiento en el año 2012 al 31 de enero de 2020, el número total de casos de infección por MERS-CoV confirmados mediante pruebas de laboratorio y notificados a la OMS a nivel mundial es de 2,519, de los cuales 866 han sido mortales. ${ }^{28}$

La evidencia disponible indica que los $\mathrm{CoVs}$ 229E, OC43, NL63 y HKU1 están bien adaptados a humanos; por lo que circulan ampliamente en la población y en la mayoría de los casos causan enfermedad leve. A la fecha, no se ha documentado ninguno de estos virus dentro de un reservorio animal. Sin embargo, en el caso de SARS-CoV y MERS-CoV, los virus no están tan bien adaptados para ser mantenidos en humanos $y$, por lo tanto, es probable que se propaguen principalmente en reservorios zoonóticos, con transmisión ocasional en la población humana susceptible y posiblemente a través de una especie hospedadora intermedia.

\section{SARS-CoV-2}

Este virus surge a finales del 2019, y se le denominó 2019-nCoV (del inglés 2019-novel coronavirus, «nuevo coronavirus de 2019») o también denominado HCoV-19 (del inglés, «human coronavirus 2019»). ${ }^{29}$ Posteriormente, el Comité Internacional de Virus lo denominó, de acuerdo con las características del genoma, como coronavirus de tipo 2 causante del síndrome respiratorio agudo severo, de manera abreviada SARS-CoV-2 (del inglés «severe acute respiratory syndrome coronavirus $2 \gg) .{ }^{30}$ Es un tipo de coronavirus causante de la segunda pandemia del siglo XXI. La primera pandemia del siglo actual fue causada por el virus de influenza A/H1N1 en 2009. Ambos virus (influenza y coronavirus) tienen en común el tropismo por el tejido respiratorio (Tabla 2).

\section{Cronología}

El 31 de diciembre de 2019, autoridades sanitarias de Wuhan, provincia de Hubei, informaron de 27 casos de pacientes hospitalizados con diagnóstico de síndrome respiratorio agudo grave de origen desconocido. La mayoría de esos pacientes estaban relacionados con el mercado de venta de animales silvestres (mercado mojado de Wuhan). Al día siguiente, decidieron clausurar el mercado de alimentos de Wuhan. Posteriormente, el 07 de enero 2020, las autoridades sanitarias de China declararon que habían descubierto la causa de la enfermedad, era un nuevo virus de la familia de los coronavirus que fue nombrado provisionalmente como 2019-nCoV (coronavirus de Wuhan). El 10 de enero 2020 se aisló el virus y se publicó la primera secuencia del nuevo coronavirus. ${ }^{17} \mathrm{Al}$ día siguiente se reportó la primera defunción y rápidamente el virus comenzó a extenderse a diversos países asiáticos como 
Tabla 2: Principales virus respiratorios que han causado alerta sanitaria y pandemias en el caso de influenza y SARS-CoV-2.

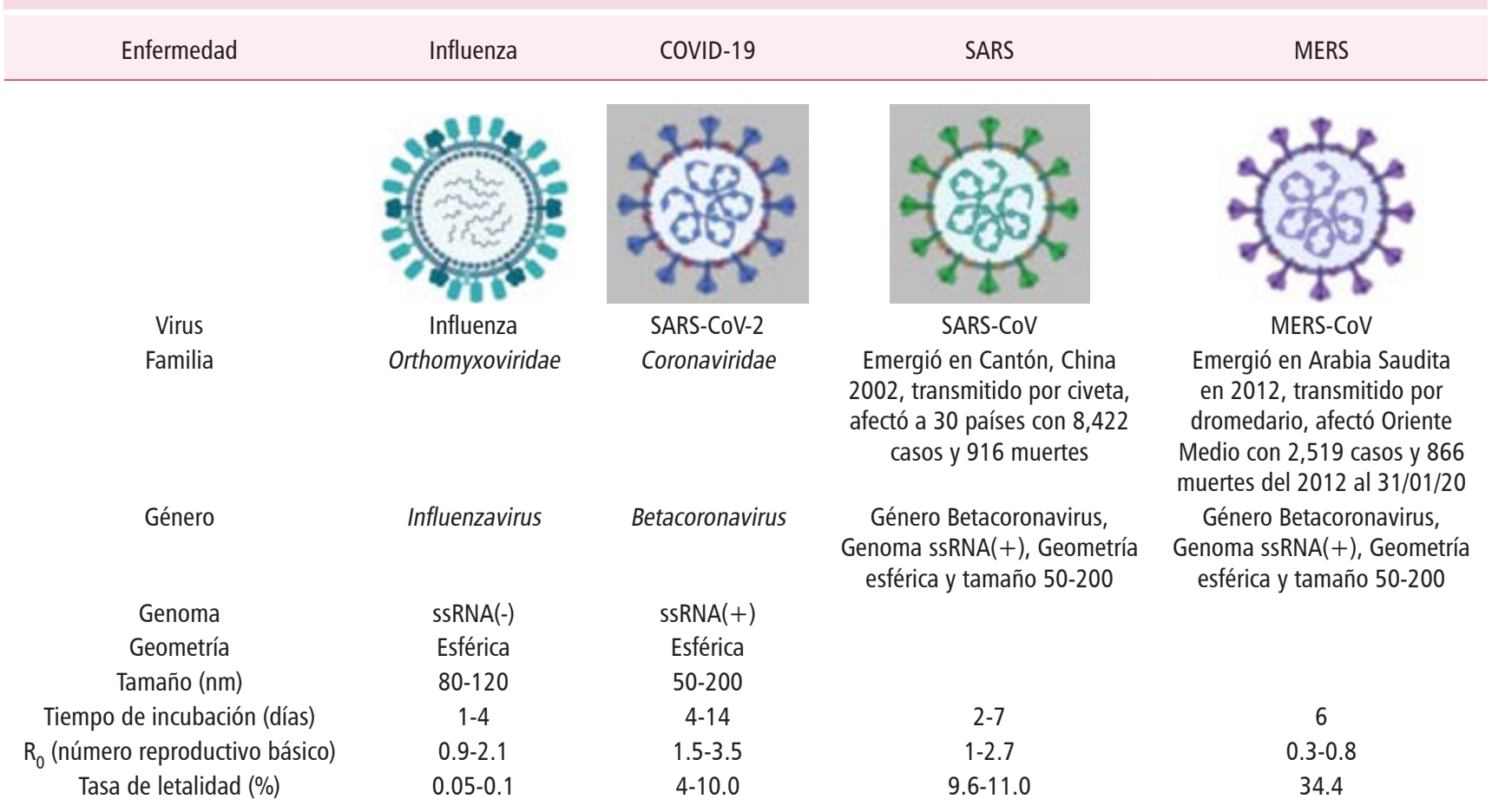

SARS-CoV-2 = severe acute respiratory syndrome coronavirus 2, SARS-CoV = severe acute respiratory syndrome coronavirus, MERS-CoV = Middle East respiratory syndrome coronavirus, $\mathrm{nm}$ = nanómetro, ssRNA(-) = virus ARN monocatenario negativo, ssRNA $(+)=$ virus ARN monocatenario positivo.

Tailandia (13/01/2020), Japón (14/01/2020), Corea $(20 / 01 / 20)$ y llegó al continente americano a Estados Unidos (21/01/20). Para el 16 de enero 2020, la OMS clasifica al virus como «riesgo moderado», posteriormente, y después de una reunión de expertos, el 23 de enero 2020 el virus se reclasifica como «riesgo muy alto y alto». ${ }^{31} \mathrm{~A}$ la par, las autoridades sanitarias en México (INDRE 24/01/20) comienzan a difundir los lineamientos de diagnóstico, indicando el requerimiento de laboratorios nivel de bioseguridad 3 (BSL-3). El 07 de febrero ajusta los lineamientos acorde con los emitidos por la OMS. ${ }^{32}$

El 26 de enero 2020, Italia emite alerta sanitaria por incremento abrupto de casos y ese mismo día Brasil reporta el primer caso. Al día siguiente Italia reporta más casos que China (lugar donde se originó el brote). El 30 de enero la OMS declara emergencia internacional y el 28 de febrero México declara los dos primeros casos, ambos con antecedente de viaje al extranjero. Es el 11 de marzo cuando la OMS declara una pandemia por el virus SARS-CoV-2 y la enfermedad la denomina COVID-19 (por sus siglas en inglés coronavirus disease 2019). ${ }^{33}$

Características del genoma y estructurales del SARS-CoV-2

EI SARS-CoV-2 es un virus de RNA de polaridad positiva (inmediatamente en el citoplasma de la célula hospedera se puede traducir a proteína como sucede con el RNA mensajero) y su genoma tiene una longitud de $30 \mathrm{~kb}$. Se cree que se originó de su pariente más cercano, BatCov RaTG13 (GenBank: MN996532), ${ }^{34}$ aislado de los murciélagos herradura. En la Figura 1 se describe la estructura del virus. Éste se compone de proteínas conocidas como estructurales: proteína $S$, espiga, espícula o del inglés spike; envoltura; membrana y nucleoproteína. Posteriormen- 
te, cuando el virus comienza su replicación requiere de proteínas no estructurales (nsp) que, como su nombre lo indica, no forman parte de la estructura del virus pero ayudan a realizar la replicación del genoma, el ensamblaje y la salida del virus. ${ }^{35}$

\section{Características de éxito del SARS-CoV-2}

Desde los primeros meses del brote de neumonía en Wuhan, ya se vislumbraba que SARS-CoV-2 cumplía con las tres características de los virus causantes de pandemias (nueva cepa, romper barrera de especie, y eficiente trasmisión de humano a humano). La primera característica que se reportó es que se trataba de una nueva cepa, perteneciente a los coronavirus. La segunda característica, romper la barrera de especie, quedaba en duda, pero estaba fuertemente asociada al mercado de venta de animales silvestres (Figura 2). Por último, la transmisión eficiente de humano a humano se hizo evidente al reportar casos positivos en los contactos de personas con diagnóstico de SARS-CoV-2, sin antecedente de visitar el mercado de Wuhan; posteriormente se reportaron casos positivos en personas con antecedente de viaje a China y también se reportaron casos positivos en personas sin antecedente de viaje (caso autóctono) (Figura 2).
A diferencia del SARS-CoV y del MERS-CoV, el SARS-CoV-2 tiene un periodo de incubación mayor, lo que le permite tener pacientes infectados pero asintomáticos (no enfermos) en contacto con más personas, por lo tanto, favorece la propagación del virus. La transmisión de persona a persona eficiente conocido como R0 es mayor para el SARS-CoV-2, con un valor de 1.5 a 3.5 , lo que indica que una persona infectada es capaz de contagiar aproximadamente a cuatro personas. Adicionalmente, SARS-CoV-2 presenta una letalidad menor comparada con el MERS-CoV por lo que el virus se puede expandir más fácilmente. Todas estas características han permitido que el virus sea exitoso y sea el causante de una de las pandemias de este siglo.

De igual manera, el SARS-CoV-2, como todos los virus con genoma de RNA, presenta mutaciones debido a la enzima encargada de copiar el genoma (RNA polimerasa dependiente de RNA o RdRp), que comete errores cada 10,000 nucleótidos. Esta característica es una ventaja evolutiva para los virus RNA. Otra peculiaridad importante y que explica la falla de los antivirales, es la actividad de exonucleasa de la proteína nsp14 (no estructural 14) que permite retirar los análogos a los nucleótidos/nucleósidos intercalados en el tratamiento. ${ }^{36}$

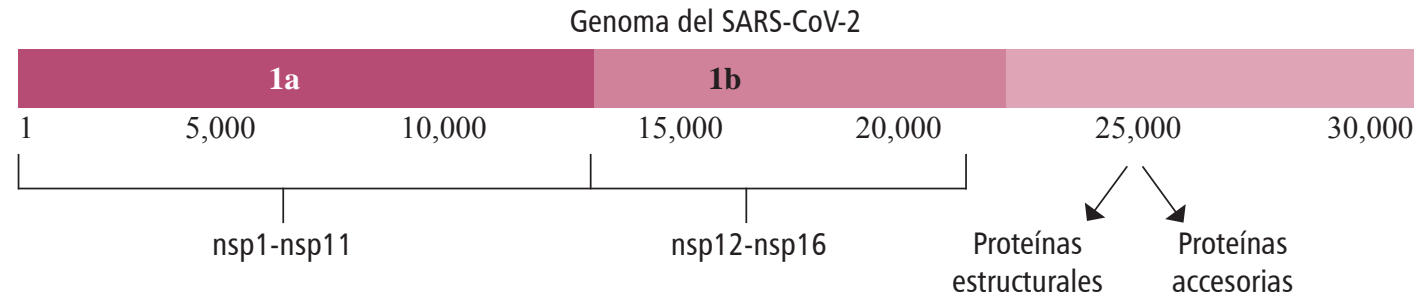

Figura 1:

$3 a, 3 b, 6,7 a, 7 b$, $8,9 b, 9 c, 10$

Genoma y estructura del virus SARS-CoV-2. Se muestra el genoma del virus SARS-CoV-2 de 30Kb o 30,000 nucleótidos, y cuenta con diferentes marcos de lectura. El marco 1a genera las proteínas no estructurales (nsp) de nsp1 a la nsp11, marco $1 \mathrm{~b}$ genera las proteínas nsp12 a nsp16. De la región

3' se generan las proteínas estructurales (espiga, envoltura, membrana y nucleoproteína) y proteínas accesorias. SARS-CoV-2 = severe acute respiratory syndrome coronavirus 2 . Figura creada con el programa BioRender.

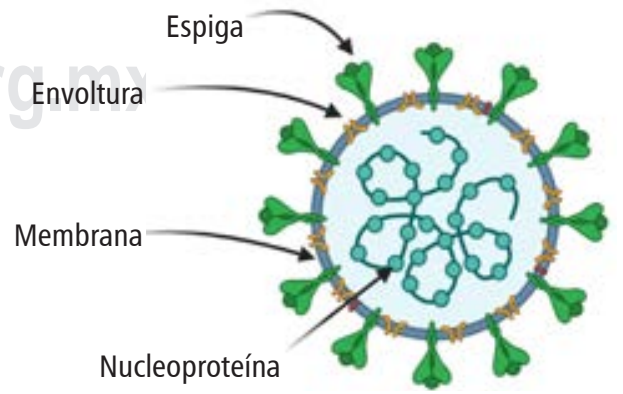




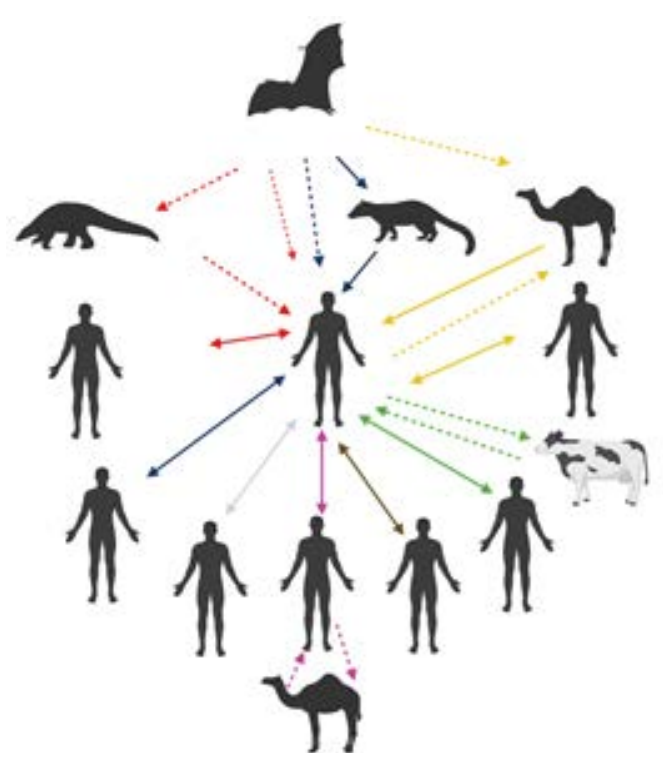

\section{DISCUSIÓN}

En el siglo pasado, el virus de la influenza causó varias pandemias. La más severa, con más de 40 millones de fallecimientos, fue en el año 1918 a causa del virus de influenza A/ H1N1 (mal denominado «gripe española»). ${ }^{37}$ Posteriormente, en 1957, el virus de la influenza A/H2N2 causó otra pandemia que inició en Asia y se extendió a todo el mundo con una mortalidad de 1.1 millones. ${ }^{38}$ En 1968 la pandemia fue causada por el virus de la influenza $\mathrm{A} / \mathrm{H} 3 \mathrm{~N} 2$, que apareció por primera vez en los Estados Unidos y la cantidad estimada de muertes fue de un millón a nivel mundial. El gran número de muertes se dio principalmente en personas mayores de 65 años. ${ }^{39}$ El virus de influenza A/H3N2 sigue circulando a nivel mundial como un virus de la influenza A estacional.

Recientemente, en este siglo XXI, la OMS ha emitido alerta epidemiológica por virus como el SARS-CoV en el año 2003, el virus del Ébola (2014) o el Zika (2015). La alerta de pandemia fue en 2009 por el virus de influenza A/H1N1 y en 2020 por el virus SARS-CoV-2. Con lo anterior, se denota que los virus capaces de causar pandemias son los respiratorios, por la manera de expandirse y de contagiar. La propagación de virus nuevos de animal a humano señalan eventos de enfermedades emergentes
Figura 2:

Coronavirus que han afectado a humanos. Las flechas de color indican la transmisión de los virus entre los hospederos animales (murciélago, pangolín, civeta, camello, vaca) y humano. La flecha continua indica la transmisión confirmada y la flecha punteada representa sospecha de transmisión. SARS-CoV-2 = severe acute respiratory syndrome coronavirus 2, SARS-CoV = severe acute respiratory syndrome coronavirus, MERS-CoV = enfermedad respiratoria vírica causada por un coronavirus, $\mathrm{HCoV}=$ coronavirus humanos.

Figura creada con el programa BioRender. con mayor potencial pandémico, ya que es más probable que estos virus se amplifiquen por transmisión de persona a persona con propagación a nivel mundial. ${ }^{40}$

A la fecha, se cuenta con vacunas para combatir la influenza; sin embargo, cuando surge una nueva cepa como sucedió en 2009, se requiere de nuevos estudios y nuevas vacunas. Como se ha visto desde 1918, el virus ha mutado para adaptarse a los humanos, aunque ha causado gran número de muertes, no es tan letal como el virus del Ébola, ${ }^{41}$ ya que un virus siempre va a requerir de una célula hospedera para replicarse y al causar mayor letalidad tiene menor probabilidad de replicarse.

Al hacer una analogía con las pandemias provocadas por el virus de la influenza y la actual pandemia provocada por el virus SARSCoV-2, es posible inferir que las vacunas no terminan con las pandemias. Los virus cambian (mutan) constantemente, y una vez que saltan la barrera de especie y son eficientes en la propagación de humano a humano se establecen en el ecosistema, circulan en el ambiente por años hasta que el sistema inmunitario es capaz de reconocerlos y tener una respuesta adaptativa. Para que esto suceda se requieren años para que el virus se reconozca como estacional y entonces las vacunas lleguen a cumplir su papel preventivo. Finalmente, en las pandemias, el 
responsable de cortar la cadena de contagios es el mismo humano, con las medidas adecuadas de prevención.

\section{CONCLUSIÓN}

La evolución biológica es un proceso multifactorial, por lo que es imposible predecir la aparición de nuevos virus (virus emergentes). Sin embargo, al evitar procesos de daño ecológico (tala indiscriminada, convivencia con animales silvestres y de granja, invasión de hábitats, etcétera) se reduce la posibilidad de epidemias y pandemias. Se puede anticipar el surgimiento de virus mutantes resistentes a los antivirales, por lo que es importante compartir la información científica de manera oportuna. Adicionalmente, es compromiso de la sociedad el cuidado de su propia salud (cambio en el estilo de vida, hábitos de alimentación, ejercicio, periodos de descanso y relajación).

\section{AGRADECIMIENTOS}

Los autores agradecen a CONACYT por los apoyos brindados (Grants: PAACTI 312807, CB-254600 y SEP-CONACYT-ANUIES-ECOS Francia: 296636), Instituto Politécnico Nacional (Grant: Proyectos Insignia IPN-2015), y COFAA-SIP/IPN (SIP 20200568).

\section{REFERENCIAS}

1. Weiss SR, Leibowitz JL. Coronavirus pathogenesis. Adv Virus Res. 2011; 81: 85-164.

2. Hamre D, Procknow JJ. A new virus isolated from the human respiratory tract. Proc Soc Exp Biol Med. 1966; 121: 190-193.

3. Farsani SM, Dijkman R, Jebbink MF, Goossens $H$, leven $M$, Deijs $M$ et al. The first complete genome sequences of clinical isolates of human coronavirus 229E. Virus Genes. 2012; 45: 433-439.

4. Tyrrell DA, Cohen S, Schlarb JE. Signs and symptoms in common colds. Epidemiol Infect. 1993; 111: 143-156.

5. Monto AS. Medical reviews. Coronaviruses. Yale J Bio Med. 1974; 47: 234-251.

6. Su S, Wong G, Shi W, Liu J, Lai ACK, Zhou J et al. Epidemiology, genetic recombination, and pathogenesis of coronaviruses. Trends Microbiol. 2016; 24: 490-502.

7. Van der Hoek L, Pyrc K, Berkhout B. Human coronavirus NL63, a new respiratory virus. FEMS Microbiol Rev. 2006; 30: 760-773.

8. Fouchier RA, Hartwig NG, Bestebroer TM, Niemeyer B, de Jong JC, Simon JH et al. A previously undescribed coronavirus associated with respiratory disease in humans. Proc Natl Acad Sci USA. 2004; 101: 6212-6216.

9. Esper F, Weibel C, Ferguson D, Landry ML, Kahn JS. Evidence of a novel human coronavirus that is associated with respiratory tract disease in infants and young children. J Infect Dis. 2005; 191: 492-498.

10. Abdul-Rasool S, Fielding BC. Understanding human coronavirus HCoV-NL63. Open Virol J. 2010; 4: 76-84.

11. Quiles MJA, Aragon DV, Monsalvo HM, Gomez DM. Non-pneumococcal bacterial pneumonias (II). Respiratory infections by Mycoplasma and Chlamydia. Viral pneumonias. Medicine (Madr). 2018; 12: 3186-3197.

12. Mclntosh K, Dees JH, Becker WB, Kapikian AZ, Chanock RM. Recovery in tracheal organ cultures of novel viruses from patients with respiratory disease. Proc Natl Acad Sci USA. 1967; 57: 933-940.

13. Poon LL, Chu DK, Chan KH, Wong OK, Ellis TM, Leung $\mathrm{YH}$ et al. Identification of a novel coronavirus in bats. J Virol. 2005; 79: 2001-2009.

14. Perlman S, Netland J. Coronaviruses post-SARS: update on replication and pathogenesis. Nat Rev Microbiol. 2009; 7: 439-450.

15. Tu C, Crameri G, Kong X, Chen J, Sun Y, Yu M et al. Antibodies to SARS coronavirus in civets. Emerg Infect Dis. 2004; 10: 2244-2248.

16. Kan B, Wang $M$, Jing $H$, Xu H, Jiang X, Yan $M$ et al. Molecular evolution analysis and geographic investigation of severe acute respiratory syndrome coronavirus-like virus in palm civets at an animal market and on farms. J Virol. 2005; 79: 11892-11900.

17. Chan JF, Kok KH, Zhu Z, Chu H, To KK, Yuan S et al. Genomic characterization of the 2019 novel humanpathogenic coronavirus isolated from a patient with atypical pneumonia after visiting Wuhan. Emerg Microbes Infect. 2020; 9: 221-236.

18. Woo PC, Lau SK, Chu CM, Chan KH, Tsoi HW, Huang Y et al. Characterization and complete genome sequence of a novel coronavirus, coronavirus HKU1, from patients with pneumonia. J Virol. 2005; 79: 884-895.

19. Woo PC, Lau SK, Yip CC, Huang Y, Yuen KY. More and more coronaviruses: human coronavirus HKU1. Viruses. 2009; 1: 57-71.

20. Woo PC, Lau SK, Tsoi HW, Huang Y, Poon RW, Chu CM et al. Clinical and molecular epidemiological features of coronavirus HKU1-associated community-acquired pneumonia. J Infect Dis. 2005; 192: 1898-1907.

21. Lau SK, Woo PC, Yip CC, Tse H, Tsoi HW, Cheng VC et al. Coronavirus HKU1 and other coronavirus infections in Hong Kong. J Clin Microbiol. 2006; 44: 2063-2071.

22. Gaunt ER, Hardie A, Claas EC, Simmonds P, Templeton KE. Epidemiology and clinical presentations of the four human coronaviruses 229E, HKU1, NL63, and OC43 detected over 3 years using a novel multiplex real-time PCR method. J Clin Microbiol. 2010; 48: 2940-2947.

23. Drosten C, Seilmaier M, Corman VM, Hartmann W, Scheible G, Sack S et al. Clinical features and virological analysis of a case of Middle East respiratory syndrome coronavirus infection. Lancet Infect Dis. 2013; 13: 745-751.

24. Zaki AM, van Boheemen S, Bestebroer TM, Osterhaus $\mathrm{AD}$, Fouchier RA. Isolation of a novel coronavirus from 
a man with pneumonia in Saudi Arabia. N Engl J Med. 2012; 367: 1814-1820.

25. Reusken CB, Haagmans BL, Muller MA, Gutierrez C, Godeke GJ, Meyer B et al. Middle East respiratory syndrome coronavirus neutralising serum antibodies in dromedary camels: a comparative serological study. Lancet Infect Dis. 2013; 13: 859-866.

26. Chan JF, Lau SK, To KK, Cheng VC, Woo PC, Yuen KY. Middle East respiratory syndrome coronavirus: another zoonotic betacoronavirus causing SARS-like disease. Clin Microbiol Rev. 2015; 28: 465-522.

27. Samara EM, Abdoun KA. Concerns about misinterpretation of recent scientific data implicating dromedary camels in epidemiology of Middle East respiratory syndrome (MERS). mBio. 2014; 5: e01430-14.

28. WHO. Coronavirus causante del síndrome respiratorio de Oriente Medio (MERS-CoV)-Reino de la Arabia Saudita. 2020.

29. Jiang S, Shi Z, Shu Y, Song J, Gao GF, Tan W et al. A distinct name is needed for the new coronavirus. Lancet. 2020; 395: 949.

30. Coronaviridae Study Group of the International Committee on Taxonomy of $\mathrm{V}$. The species Severe acute respiratory syndrome-related coronavirus: classifying 2019-nCoV and naming it SARS-CoV-2. Nat Microbiol. 2020; 5: 536-544.

31. OMS. Declaración del Director General de la OMS relativa a la reunión del Comité de Emergencia del RSI sobre nuevos coronavirus.
32. Martínez BM. Protocolo de bioseguridad y biocustodia para el manejo de pacientes durante la toma de muestras de casos probables por enfermedad por 2019-NCOV 2020.

33. WHO. World Health Organization. Novel coronavirus. 2020.

34. Zhou P, Yang XL, Wang XG, Hu B, Zhang L, Zhang W et al. A pneumonia outbreak associated with a new coronavirus of probable bat origin. Nature. 2020; 579: 270-273.

35. Yoshimoto FK. The Proteins of Severe Acute Respiratory Syndrome Coronavirus-2 (SARS CoV-2 or n-COV19), the Cause of COVID-19. Protein J. 2020; 39: 198-216.

36. Romano M, Ruggiero A, Squeglia F, Maga G, Berisio R. A structural view of SARS-CoV-2 RNA replication machinery: RNA synthesis, proofreading and final capping. Cells. 2020; 9 (5): 1267.

37. Liu WJ, Bi Y, Wang D, Gao GF. On the centenary of the spanish flu: being prepared for the next pandemic. Virol Sin. 2018; 33: 463-466.

38. Enfermedades CpeCylPd. Pandemia de 1957-1958 (virus H2N2). 2020.

39. Enfermedades CpeCylPd. Pandemia de 1968 (virus H3N2). 2020.

40. Kreuder Johnson C, Hitchens PL, Smiley Evans T, Goldstein T, Thomas K, Clements A et al. Spillover and pandemic properties of zoonotic viruses with high host plasticity. Sci Rep. 2015; 5: 14830.

41. Holmes EC, Dudas G, Rambaut A, Andersen KG. The evolution of Ebola virus: Insights from the 2013-2016 epidemic. Nature. 2016; 538: 193-200. 